\title{
Historical perspectives of The American Association for Thoracic Surgery: David J. Dugan (1910-1998)
}

\author{
James I. Fann, MD, for The American Association for Thoracic Surgery Centennial Committee
}

David J. Dugan, the 56th president of The American Association for Thoracic Surgery (AATS), was born in Oshkosh, Wisconsin, on June 29, 1910 (Figure 1). Growing up in the Midwest, he attended John Carroll University in Ohio, from which he graduated in 1932. He matriculated at St Louis University Medical School, receiving his doctorate in 1936. Interested in general surgery, he completed training at St John's Hospital in Cleveland in 1939 and embarked on a career in private practice in Lakewood, Ohio. With the involvement of the United States in World War II and 2 years of general surgery practice experience, he entered the Armed Service in September 1942.

Dugan was assigned to the thoracic surgery service under the direction of Brian Blades (37th AATS president) at Walter Reed General Hospital. On entering the Army, Dugan and 9 other medical officers were handed instructions for "Temporary Duty for a period of approximately 6 weeks for the purpose of pursuing a course of instruction in thoracic surgery" at the University of Pennsylvania. ${ }^{1}$ It is by this route that Dugan began his training in thoracic surgery, a specialty that he "barely knew existed" and a specialty choice that was unsolicited and was "explained only by the unpredictable wisdom of the United States Army."1-3

When the United States entered World War II, thoracic surgery was not yet considered a distinct specialty. Because of its undefined status during the War, no consultant specializing in thoracic surgery was formally appointed in any oversea theater. ${ }^{4}$ On the basis of subsequent surgical outcomes of the famed Second Auxiliary Surgical Group in the Mediterranean and European theaters, Lyman A. Brewer III (54th AATS president), Paul C. Samson (48th AATS president), Thomas H. Burford (51st AATS president), and others made a compelling case for the establishment of thoracic surgery as a distinct specialty. ${ }^{5,6}$ In the United States, the situation was different. By 1938, the AATS had 14 honorary members, 99 active members, 69 associate members, and 30 senior members. ${ }^{4}$ Largely from this AATS group, active and associate members were selected

From the Department of Cardiothoracic Surgery, Stanford University, Stanford, Calif. Disclosures: Author has nothing to disclose with regard to commercial support.

Received for publication April 3, 2012; accepted for publication May 10, 2012; available ahead of print June 18, 2012.

Address for reprints: James I. Fann, MD, Department of Cardiothoracic Surgery, Stanford University, 300 Pasteur Drive, Stanford, CA 94305 (E-mail: jfann@ stanford.edu).

J Thorac Cardiovasc Surg 2012;144:297-9 $0022-5223 / \$ 0.00$

Published by Elsevier Inc. on behalf of The American Association for Thoracic Surgery

doi:10.1016/j.jtcvs.2012.05.023 as the directors of thoracic surgery centers, heads of thoracic surgery services, and members of thoracic surgical teams. In July 1942, Blades was assigned to Walter Reed Hospital with the specific mission of setting up a thoracic surgery service. To fulfill the Army mission to increase the number of surgeons trained in thoracic surgery, academic institutions, such as Columbia University, University of Michigan, University of Pennsylvania, and Washington University in St Louis, created an intensive 6-week training course in thoracic surgery for those who had previously completed general surgery training. ${ }^{4}$ During this career-altering training course, Dugan reflected, "We had no practical experience, but we did have the opportunity to observe such men as Clerf and Chevalier Jackson while they were at work." ${ }^{4}$ Further, he noted, "...chest surgical operations were not frequent, and the only such procedure to which we were invited during the entire 6 weeks was a thoracotomy by Emory Burnett in which he removed a mediastinal dermoid.",

After his brief training at the University of Pennsylvania, Dugan returned to duty at Walter Reed. As luck would have it, on his return, a large convoy of chest casualties arrived, and his only qualification for providing thoracic surgical care was the course that he had just completed. ${ }^{4}$ Fortunately for Dugan, he was supervised by and received additional training from Blades, who remained in charge of the thoracic surgery service at Walter Reed throughout the War. Under Blades' leadership, by the time the first casualties arrived from North Africa in late 1942, the thoracic surgery service at Walter Reed Hospital had its own ward and medical staff. ${ }^{4}$ Incidentally, shortly after his arrival at Walter Reed, Blades performed the first pneumonectomy at an Army hospital in September 1942 using perioperative resources that he implemented. ${ }^{4}$ Not unexpectedly, there was disapproval of his boldness in undertaking this case; the patient made an excellent recovery, however, and performing such a procedure likely readied the staff for the subsequent war-related casualties. In March 1943, Walter Reed Hospital was designated a thoracic surgery center, and as such it continued to expand until the end of the War. Also during this time, antibiotics such as the sulfonamides and penicillin, discovered in 1928, were being clinically evaluated and held great promise in the management of soft tissue, systemic, and pulmonary infections. ${ }^{1,5,6}$

For the next 3 years during the War, Dugan worked under the tutelage and mentorship of Blades. Because of the prominence of Walter Reed Hospital, visiting dignitaries were frequent during his tenure. One eminent individual at Grand Rounds was the Secretary of War Henry L. 
Stimson. Dugan fondly recalled, "Dr Blades, of course, conducted the bedside rounds and my responsibility, being the other half of the Service, was to present the individual cases. At that particular stage of my physical development, I weighed 120 pounds and had not overcome the typical hospital pallor of my training days." ${ }^{1}$ To show interest, the Secretary inquired "What is it, Captain Blades, that determines when you place the patients on the seriously ill list?" Blades responded dryly, "When they begin to look like Lieutenant Dugan."1

At Walter Reed and other institutions, Dugan drew inspiration from then and future leaders in thoracic surgery. Assigned to his service was Donald B. Effler, who later was to gain prominence in cardiac surgery as the Chief of Thoracic and Cardiovascular Surgery at the Cleveland Clinic. ${ }^{1}$ One individual who had a profound impact on Dugan was John C. Jones (45th AATS president), a pioneer chest surgeon in Los Angeles who went on to establish the cardiothoracic surgery training program at the University of Southern California; to Dugan, Jones demonstrated true professionalism with his calm and gentle manner combined with his surgical excellence and patient concern. Although it was clear that Dugan was to pursue a career focused on thoracic surgery, there were times when he still clung to his "original intent to get it over and go home" to his general surgery practice. ${ }^{1}$

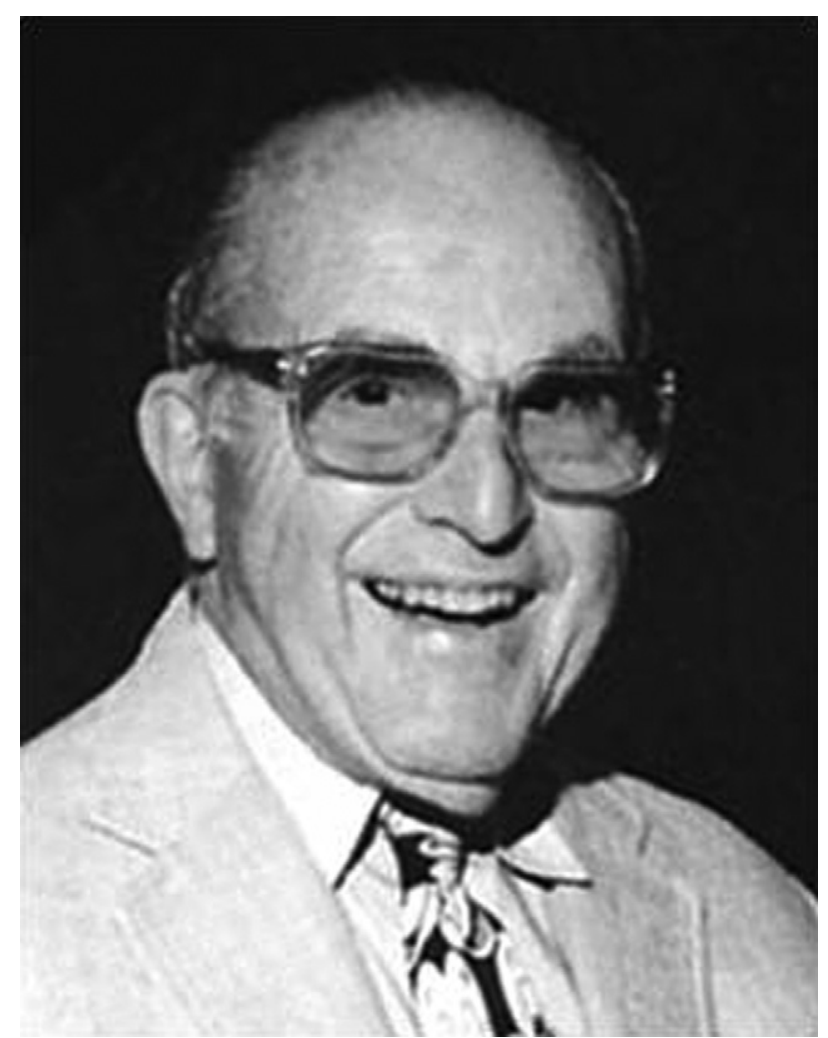

FIGURE 1. Photograph of David J. Dugan. Reprinted with permission. ${ }^{3}$
Toward the end of the War and in recognition that Dugan's experience in surgical treatment of tuberculosis was limited, Blades insightfully managed to have Dugan transferred to Fitzsimmons General Hospital in Denver, Colorado, as Chief of the Thoracic Surgery Service for the remainder of his military service from August 1945 to September 1946. ${ }^{1,4}$ A mecca for tuberculosis therapy, the environment of Fitzsimmons completed his thoracic surgery training, providing him with a breadth of operative experience. By working with John Grow, a brilliant chest surgeon and close friend, and James Forsee, who had returned from the Second Auxiliary Surgical Group, Dugan's career in thoracic surgery flourished and was sealed. ${ }^{1}$

Released from the Army in September 1946, Dugan entered private practice in thoracic surgery in partnership with Paul Samson in Oakland, who was one of the first surgeons in the West to limit his scope of practice to thoracic surgery before the War. ${ }^{7,8}$ As Dugan's mentor, Blades had introduced him to Samson at the 25th Annual Meeting of the AATS in Detroit and then sent him to the American College of Surgeons meeting in San Francisco to have follow-up discussions with Samson. From these early interactions, Samson and Dugan established an enduring friendship and thoracic surgery partnership lasting more than 30 years. Early in their practice, they focused their efforts on drainage of pleural empyemas and bronchoscopy; soon, Dugan found that they became highly adept at removing foreign bodies from their pediatric clientele. ${ }^{8}$ As intrathoracic approaches to pulmonary infection and resectional procedures for malignancy became "safe and natural," the scope of their practice and that of surgeons throughout the country broadened. ${ }^{8}$

From his clinical observations and experience, Dugan reflected that "the standardization of individual ligation in pulmonary resection has done more to establish and advance the specialty of thoracic surgery than any other single contribution." "He authored 39 scientific articles pertaining to war wounds of the chest, chest infections, pulmonary resection for tuberculosis and tumor, esophageal tumors and perforations, mediastinal tumors, and phrenic nerve injury, In 1952, Dugan reported 16 cases of esophageal perforation, 11 of which were due to endoscopic procedures, and discussed the treatment and proposed cause of such injuries in iatrogenic perforations. ${ }^{9}$ In 1956, along with Joseph F. Sadusk and Samson, Dugan outlined the responsibility of the thoracic surgeon in the relatively new field of cardiac surgery. ${ }^{10}$

Dugan met his wife, Lucille Skelly, during his surgical training, and they married in $1940 .^{3}$ After he retired from practice, they moved to St Helena in the Napa Valley. She died at the age of 80 years on February 4, 1992. As friend and colleague Quentin Stiles recounted, Dugan and Lucille's love affair lasted even beyond their 52-year union. ${ }^{3}$ As was his custom, Dugan went on a daily bicycle ride of 10 miles 
that inevitably took him to her grave site. On one visit, Stiles bicycled with Dugan to Lucille's grave and witnessed Dugan having a heartfelt conversation with Lucille. ${ }^{3}$ During retirement, Dugan continued to focus his energy for the benefit of others, including the creation of a medical clinic for migrant workers in the Napa Valley. He actively volunteered in the community and regularly served coffee at the Farmers Market on Fridays and was known as "Dr Coffee." His favorite activity was tutoring fourth-grade elementary school students who were having difficulty with English. On May 12,1998 , Dugan died suddenly at his home. ${ }^{3}$

In his presidential address at the Annual Meeting of the AATS in 1976, Dugan made a convincing case to avoid the splintering of cardiac and thoracic surgery and the need to maintain both components as part of the Board examination. ${ }^{1} \mathrm{He}$ also insightfully and prophetically proposed shortening the training process to a total of 6 years. With the advances in cardiac surgery at that time, Dugan observed,

"This has given the risk to the feeling of many that a special board of cardiac surgery be established. Conversely, surgeons interested in general thoracic surgery, and not in cardiac, feel that the requirement of training in heart surgery is not in their situation essential.... Heart surgeons are now doing cardiac operations with great facility in the large centers and are being dispersed throughout our communities. While their performance in heart operations is unquestioned, it seems to me in the event the need for heart surgery may not continue in their particular practice, they should have sufficient training in operations elsewhere in the thoracic cavity to satisfy community needs. The general thoracic surgeon likewise should have sufficient cardiac exposure to make certain that familiarity with heart surgical problems makes him comfortable in that area... By all means, both cardiac and general thoracic surgeons should come under the American Board of Thoracic Surgery without splintering into 2 separate groups."

Dugan believed that the training time could be reduced, requiring 3 years of general surgery and 3 years of thoracic and cardiac surgical training. Thus, in a total of 6 years, the trainee should be able to acquire sufficient experience in both areas to allow him or her to pass the cardiac and thoracic components of the Board examination. ${ }^{1}$

In December 1973, Dugan, Arthur Thomas, and Buford Burch founded the Samson Thoracic Surgical Society in honor of and without the prior knowledge of Samson. ${ }^{2,7,8,11}$ The inaugural dinner was held in June 1974 in San Francisco, and the first annual meeting was held in May 1975 in Santa Barbara. ${ }^{2}$ In 1983, after Samson's death, the Samson Thoracic Surgical Society was renamed the Western Thoracic Surgical Association to achieve representation at the American College of Surgeons Board of Governors, which did not recognize societies named for an individual. ${ }^{11}$ Dugan was not only the original and 3-time president of the Western Thoracic Surgical Association but he was also its driving force. The Western Thoracic Surgical Association David J. Dugan Distinguished Service Award is presented to a member in recognition of distinguished and outstanding contributions to the field of thoracic surgery over a sustained period.

Quentin Stiles noted that Dugan was the "consummate physician and ultimate humanitarian." ${ }^{3}$ He strongly valued personal relationships, and those "who met him came away a little better for the experience." "At the conclusion of his AATS Presidential Address, Dugan urged, "Finally, may we continue to conscientiously practice and deliver our services with a dedication and devotion deserving of the patients who seek our help. Let us all strive to be mature in youth, youthful in old age, adorned with the grace of wit, wise, kind, faithful in friendship, and in all dealings, tolerant and humane." 1

\section{References}

1. Dugan DJ. The challenge of progress. J Thorac Cardiovasc Surg. 1976;72:1-6.

2. Jones KE. Twenty-five years of excellence: the legacy and the challenge. J Thorac Cardiovasc Surg. 2000;119:203-9.

3. Stiles QR. In memoriam: David J. Dugan (1910-1998). J Thorac Cardiovasc Surg. 1998;116:383-4.

4. Blades B, Carter BN, DeBakey ME. Chapter V: Administrative considerations in the zone of interior. U.S. Army Medical Department, Office of Medical History. Available at: http://history.amedd.army.mil/booksdocs/ wwii/thoracicsurgeryvolI/chapter5.htm. Accessed February 11, 2012.

5. Brewer LA III. The contributions of the Second Auxiliary Surgical Group to military surgery during World War II with special reference to thoracic surgery. Ann Surg. 1983;197:318-26.

6. Fann JI. Historical perspectives of The American Association for Thoracic Surgery: Lyman A. Brewer, III (1907-1988). J Thorac Cardiovasc Surg. 2011 Aug 4 [Epub ahead of print].

7. Fann JI, Connolly JE. Historical perspectives of The American Association for Thoracic Surgery: Paul Samson (1905-1982). J Thorac Cardiovasc Surg. 2011;142:967-9.

8. Dugan DJ. Paul C. Samson, M.D., 1905-1982. Part II. Personal recollections. Ann Thorac Surg. 1983;36:502-4.

9. Dugan DJ. The management of esophageal perforations. Chest. 1952;22:556-69.

10. Dugan DJ, Sadusk JF Jr, Samson PC. The responsibility of the general thoracic surgeon in cardiac surgery. Chest. 1956;29:153-65.

11. Pomerantz M. Brief history of the Western Thoracic Surgical Association. Available at: http://www.westernthoracic.org/about_history.html. Accessed February $11,2012$. 